\title{
Baltic Sea ice and environmental and societal implications from the comparative analysis of the Bay of Bothnia and the Gulf of Riga
}

\author{
ÉLISE LÉPY
}

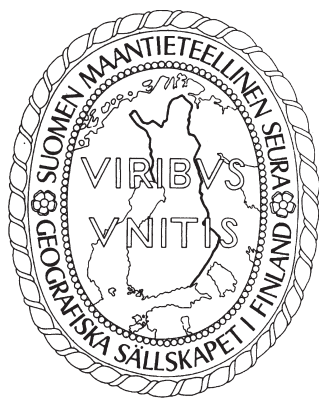

Lépy, Élise (2012). Baltic Sea ice and environmental and societal implications from the comparative analysis of the Bay of Bothnia and the Gulf of Riga. Fennia 190: 2, pp. 90-101. ISSN 1798-5617.

This article contributes to many studies on sea ice often carried out by geophysicists and rarely by geographers. Thus, it aims to understand climatic and marine processes of ice formation and break-up of littoral waters and coastal sea, and their environmental, economic and societal consequences in the Baltic Sea. The interest of this research lies in the comparative analysis of two regions: the Bay of Bothnia and the Gulf of Riga. These two case studies are politically, economically and culturally different and help to understand the diversity of reactions and adaptations to the human management of the natural constraint imposed by sea ice phenomena. By using a systemic approach, quite common when studying geographical issues of nature and societies, the work has contributed to a better knowledge of the natural environment of Baltic Sea ice showing a significant interannual variability and a spatial internal diversity of sea ice conditions in the Baltic Sea. It also raises the questions of the environmental determinism which is rejected by the remarkable adaptability of coastal population. Finally, the socio-economic implications of historical changes of sea ice features are emphasized showing that future Baltic Sea ice conditions should be carefully considered when talking about global evolution.

Keywords: Baltic, sea ice, systemic approach, societies, shipping, risks

Élise Lépy, Faculty of Humanities \& Thule Institute, University of Oulu, P.O. Box 7100,90014 University of Oulu, Finland.E-mail: elise.lepy@oulu.fi

\section{Introduction}

The Baltic Sea is known to be one of the northernmost seas of Europe which freezes every winter contrary to the Norwegian and North Seas located at similar latitudes. Included in the Northern European temperate continental zone (Planchon 1997), the Baltic Sea is attached to the polar environment in winter, and to temperate latitudes in summer (Pagney 1989). Geographical conditions of the Baltic Sea are favourable to landscape transformation due to seasonal variations of climate. In fact, the harshness of winter temperatures is the main driving force of ice formation of Baltic waters even if currents, waves and winds contribute to the irregular cooling of these waters. Baltic sea ice characteristics (Fig. 1) can vary interannually: the maximum ice extent can cover 10 to $100 \%$ of its surface area, the ice season varies from four to seven months, and the maximum ice thickness can reach 120 centimetres (Jevrejeva et al. 2004). Many authors and researchers have taken an interest in the Baltic Sea, one of the most studied seas in the world (Guilcher 1958).

The scientific contribution of Finnish and Swedish research has been significant since the $19^{\text {th }}$ century when the first measurements of ice thickness and ice formation and disappearance dates were recorded. Scientists have observed, analysed and studied the nature of Baltic Sea ice for the development of winter navigation (Vihma \& Haapala 2009). In 2001, Matti Leppäranta et al. published a key article on geophysics of Baltic Sea ice since the $19^{\text {th }}$ century. With the development of winter maritime traffic, observation stations have been installed along the Baltic coasts and one of the main motivations of scientific research has been to study the ice process. The Finnish Institute of Marine Re- 
search was created in 1918 in order to realise cartographic monitoring of sea ice conditions and study navigation conditions. In 1937, Risto Jurva presented in his academic dissertation a cartographic system for evaluating ice conditions. He studied climatological conditions required for ice formation and the evolution of the maximum ice extent of the Baltic since 1720 (Jurva 1952a, 1952b). In 1953, Erkki Palosuo improved Jurva's cartographic system by including severe winter conditions and deeply described for the first time the geophysics of Baltic Sea ice. In the sixties, the Finnish-Swedish collaboration led to the construction of a climatological ice atlas (1982) which is still the only one to provide detailed information on Baltic Sea ice. Since the seventies, works have been made on geomorphological impacts of ice movement on the shores. Thus, Jouko Alestalo and Jukka Häikiö (1976) mapped the evolution of the coastline in relation with ice accumulation (Alestalo et al. 1986) on Bothnian Bay's shores. In the nineties, a series of field experiences took place in Finland for exploiting radar data from ERS-1 satellite launched in 1991 (Thompson \& Leppäranta 1987; Leppäranta \& Thompson 1989, Leppäranta \& Lensu 1992; Leppäranta et al. 1998). During the last decade, more attention has been brought on environmental issues especially for pollution and protection matters through the analysis of Baltic Sea ice.

In this article, the research approach is very different from previous studies on Baltic Sea ice since it covers physical and human aspects of geography and therefore deals with environmental and societal themes. The originality of this work relies on the geographical study of sea ice - currently uncommon in this field of research - and on the approach of global geography dealing with environment-humans relations issues and raising the question of physical determinism or societal adaptability to this "constrained" environment. For this research, two case studies have been conducted: the Finnish coast of the Bay of Bothnia and the Latvian coast of the Gulf of Riga. The study of these two coastal areas allows us to understand the ways in which two economically, politically and culturally different countries are able to face constraints and advantages of sea ice phenomena ${ }^{1}$. While Finland joined the European Union (EU) in 1995, Latvia became a member of the EU in 2004 after 18 years of independence and 50 years of Soviet occupation and assimilations.
The research problems and objectives of this comparative analysis are summarized below:

I. Works on Baltic Sea ice have been numerous with very specific approaches especially in geophysics, but they have not really considered all the elements, physical and human, of the environment. This study contributes to a better knowledge of Baltic Sea ice showing the obvious relationships between the natural environment and the coastal population's practices.

II. The effects of the sea ice formation on natural and human environments are determined by the spatial and temporal variability of ice phenomena. Sea ice conditions inevitably differ from one site to another according to the natural driving forces responsible for ice formation and disappearance. This research studies the physical features of Baltic Sea ice by highlighting the relationship between climate and sea ice and by analysing the geomorphological action of sea ice on the evolution of the coastlines.

III. The seasonality of this natural process engenders major and recurrent effects on societal and economical aspects. Through the analysis of societal behaviours of Finnish and Latvian populations, divergences of responses to winter adaptation and seasonal appearance of new exploitation forms are investigated taking into account the differences in history, economy and culture. The study is dedicated to the analysis of sea ice perception by coastal populations via their practices, to the winter navigation and to the risks induced by sea ice.

IV. Subpolar and arctic seas are at the heart of many scientific works since their future arouses environmental questions strongly linked to the global warming issue. Moreover, it has been demonstrated that ice formation and melting certainly shows the historical variability of thermal warming and cooling on Earth. This work analyses the history and variations of Baltic Sea ice during the past centuries and defines the direct effects of a regional increase of temperatures on Baltic Sea ice conditions and indirect socio-economic impacts on their surroundings.

\section{Methodological approach and data}

For this geographical scientific research, a classical inductive approach has been used highlighting 


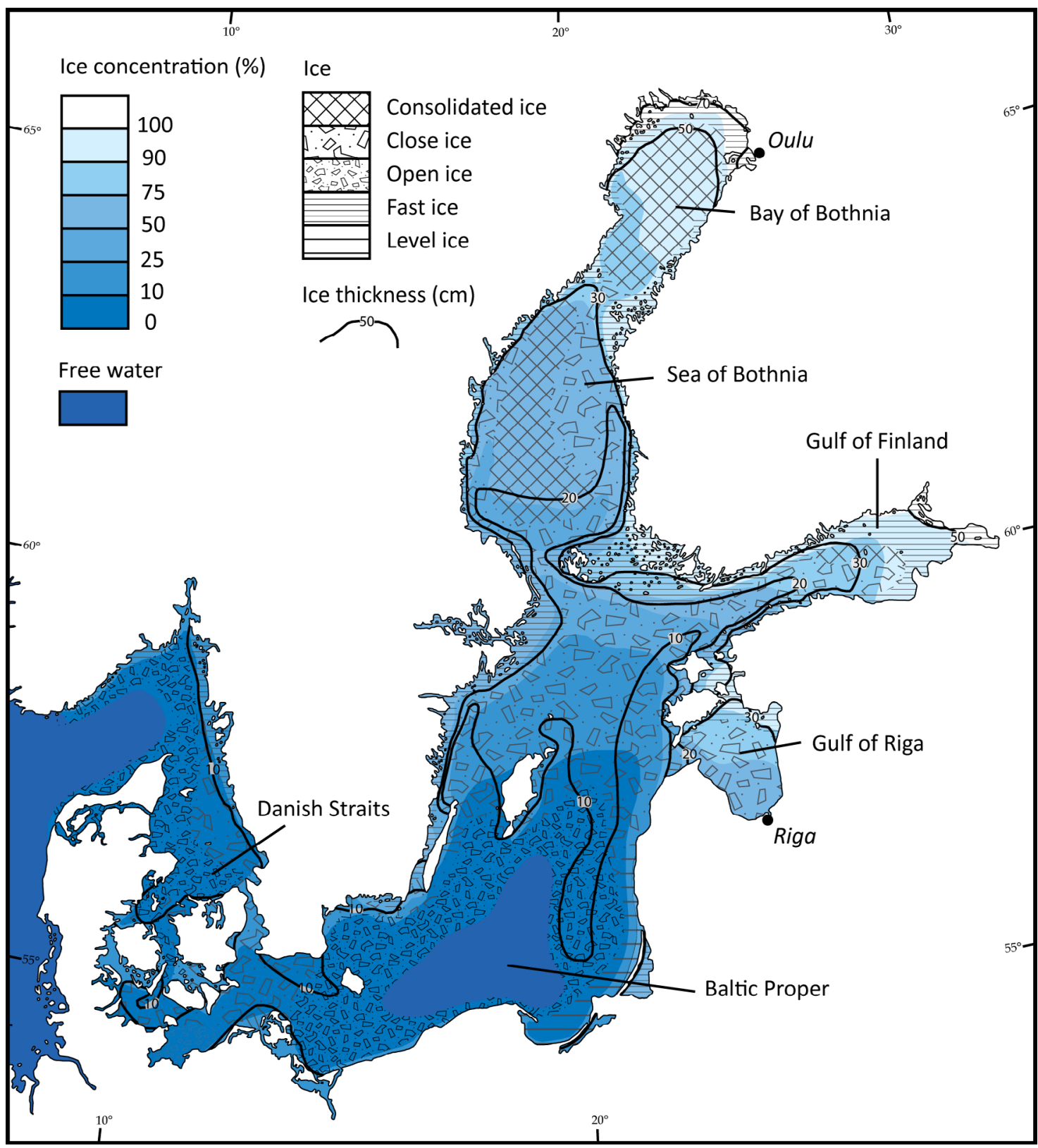

Fig. 1. Average ice conditions in the Baltic Sea on March 1 ${ }^{\text {st }}$. Data source: Swedish Meteorological and Hydrological Institute \& Finnish Institute of Marine Research 1982.

the role of the steps of observation and fact description preceding most of the time the construction of theories. The inductive approach involved a lot of fieldwork in both case studies: over 20 months in total were spent in Oulu, where the au- thor was hosted by the Department of Geography of the University of Oulu and three months in Riga, hosted by the LEGMA (Latvian Environment, Geology, and Meteorological Agency). This made it possible to collect data and treat it using qualita- 
tive and quantitative methods, fundamental within the systemic approach.

The qualitative approach was based on three main elements: the field observation, the interviews and the analysis of literature sources. The field observation, essential to any geographical approach, focused on the ice growth and melting processes in the Bay of Bothnia and the Gulf of Riga and on societal behaviour to the seasonal ice formation. Semi-structured interviews were conducted with administrative personnel of various institutions and with local actors of sea ice.

Statistical treatments of both quantitative and qualitative data were realised. A large work was done with climate data of the meteorological stations of Oulu (data available from 1873 to 2007) and Riga (data available from 1795). Statistical data related to sea ice conditions was also used such as the dates of ice formation and disappearance, the ice thickness and the ice extent. Other statistical data included the winter traffic restrictions and accidents on sea ice. Moreover, a survey was set up dealing with sea ice and related human activities and targeting coastal populations of Oulu (105 responses) and Riga (100 responses). Results were processed using the Chi-square test and Tschuprow coefficient. Finally, mapping methods such as satellite images were used for the spatialization of phenomena.

\section{Results}

The Baltic Sea waters have the particularity to freeze every winter for few months and this can easily be explained by the environmental context favouring the ice formation. The geomorphological context, especially the type of coasts and the seabed depth, has an important role in ice processes, as well as the morphology of the marine intra-continental basin of the Baltic Sea, 415,000 $\mathrm{km}^{2}$, which was previously recovered by the north European Quaternary ice sheet (Tikkanen \& Oksanen 2002; Eronen 2005). Moreover, this semi-enclosed basin limits the sea water exchange through the Danish Straits between the North Sea and the Baltic Sea. Thus, the ice growth is largely favoured by the low rate of salinity of Baltic brackish waters, $3 \%$ in the Bay of Bothnia and 10-13\% in the Baltic Proper (Kullenberg 1981), due to a major contribution of continental waters (hydrological basin of 1,7 million $\mathrm{km}^{2}$ ) and to the internal water circulation. However, the ice formation is mainly a cli- matic phenomenon and therefore considered as a major component of the climate system of polar and subpolar regions (Leppäranta 1993; Haapala 2000). In fact, the continentality of the Baltic Sea climate described by Roussel (1989) shows the clear and major role of winter negative air temperatures in ice formation. The evident relationships have been shown between winter air temperatures and sea ice related variables such sea ice extent, ice thickness and ice season length (Lépy $2007,2009)$. Moreover, local meteorological conditions have an effect on the sea ice formation and variability. These natural forcing factors are responsible for the spatial and temporal variability of sea ice and its fluctuations.

\section{Spatial and temporal variability of sea ice}

The freeze-up of the Baltic Sea waters is a seasonal phenomenon whose probability of occurrence is equivalent to $100 \%$ annually. However, the interannual variations of sea ice features are broad. In fact, during the last century, despite an average maximum extension of about $50 \%$, sea ice extent has ranged from 12 to $100 \%$ of the Baltic Sea surface and the ice season from four to seven months (Leppäranta 1993). The spatial and temporal variability of sea ice processes seems to be more significant in southern sea waters of the Baltic Sea. The probability of occurrence of sea ice formation shows spatial and temporal disparities. Waters of the Bothnian Bay freeze every winter contrary to waters of the Gulf of Riga whose ice growth rate fluctuates sensibly. The Southern Baltic is generally more sensitive to air temperature changes due to the latitudinal position. This variability is more noticeable when the ice season starts. Moreover, inland water flows largely participate to these variations.

\section{Interactions between sea ice and the environmental context}

Interactions between Baltic Sea ice and its environment naturally exist and mainly concern the atmosphere through energy transfer and the coastal morphology. In fact, based on the observations made on the Finnish coasts of Oulu and Hailuoto, and the Latvian coasts of Riga and Jurmala and based on the previous geomorphological studies conducted by Alestalo and Häikiö (1976) and Eberhards (2003), it has been noticed a very limit- 


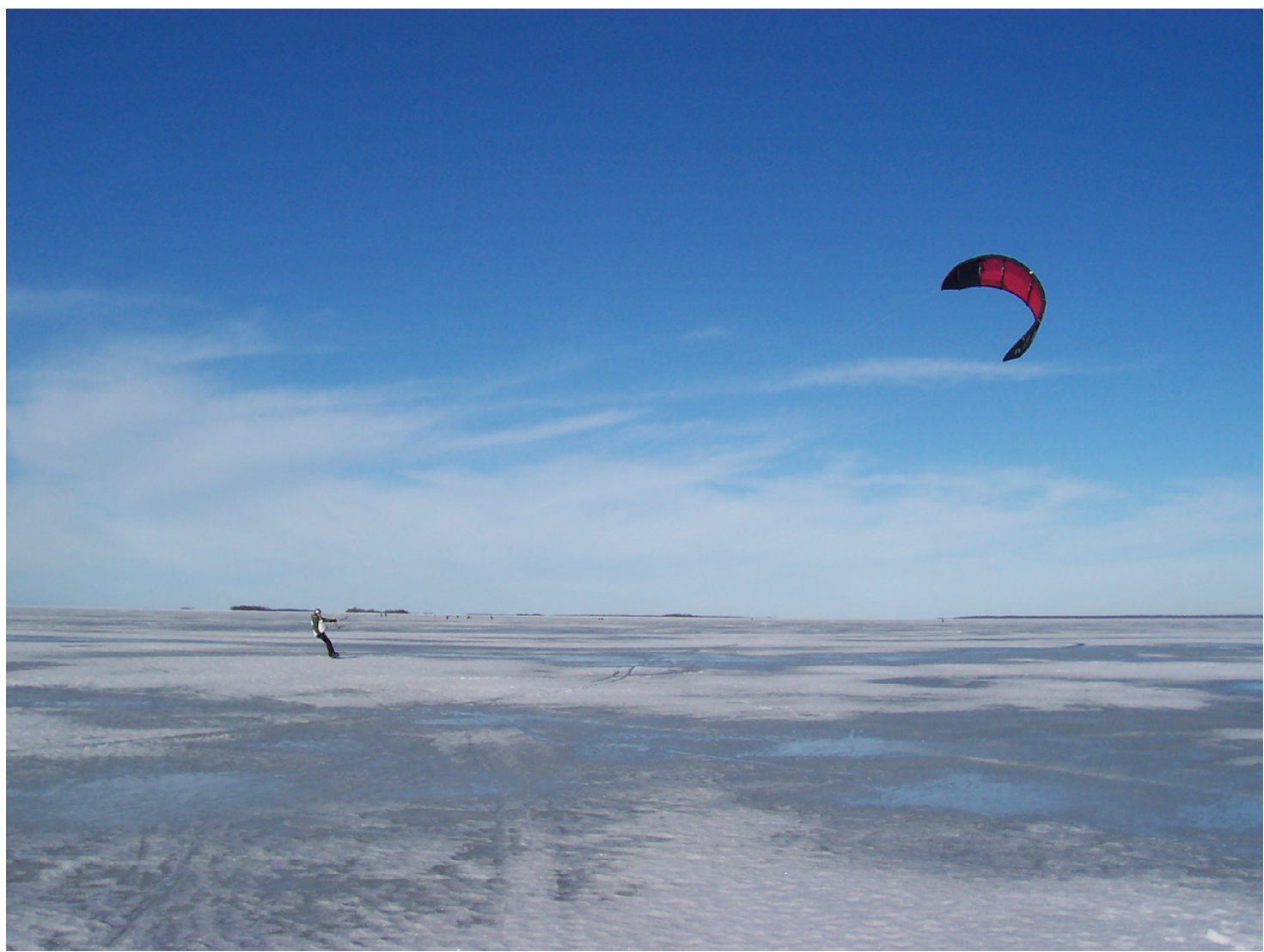

Fig. 2. Kitesurfing on sea ice, Nallikari, Oulu - March $17^{\text {th }} 2007$. Photo taken by Élise Lépy.

ed erosive role of sea ice on the coast. Coastal ridged and rafted ice accumulates when weather and marine conditions are harsh but anyhow these sea ice deformations do not really participate to the geomorphological changes of the coasts. Moreover, the sediment transportation by floating ice is not significant enough to modify the sediment budget of beaches. Consequently, the Baltic Sea ice has more a coastal protective role against common erosive agents such wind and waves.

\section{Societal implications and coastal population adaptability}

Other results consider societal, cultural and economic implications and the degree of intensity of the relationships between the marine environment and the Finnish and Latvian societies within sea ice-related study. The possible reasons for a more or less good adaptation to sea ice and its percep- tion by local populations as an asset or a constraint were analysed. Field observations and statistical treatment of survey responses show first of all that $86 \%$ of the local Finnish population of Oulu go to sea ice at least once during the winter season while over $50 \%$ of the local Latvian population of Riga-Jurmala never go. Results need to be carefully interpreted since only few people walking on sea ice have actually been observed in Jurmala, the rest of the people walking on the snowy beach. Secondly, different significant disparities have been demonstrated such as the perpetuation of traditional activities in Oulu region and the fear of sea ice on Latvian coasts. In fact, forms of occupation and exploitation are various in Northern Baltic where traditional activities such as cross-country skiing, walking, ice fishing, seal hunting, ice skating and postmodern sports and recreational activities like snowmobile driving and kitesurfing (Fig. 2) are common sea ice activities for Finnish 
people. On the contrary, in Riga-Jurmala sea ice is an ignored if not feared area where activities are almost inexistent. For that matter, the survey discloses that more than $60 \%$ of the population of Oulu perceive sea ice as a low danger area, even not dangerous at all, while $10 \%$ of the same population consider it as dangerous or even very dangerous. In Latvia, $45 \%$ of the people interviewed think that sea ice is potentially dangerous or even very dangerous and only $23 \%$ perceive it as a minor danger. Dissimilar frequencies in ice growth of waters of both sites as well as contrasting sociocultural factors such marine-related occupation, real-life experience on sea ice, historical and cultural characteristics, economical level and means of information and communication explain these disparities.

Despite the lower extension, thickness and stability of sea ice in the Gulf of Riga, the study has shown that the theory of the environmental determinism cannot explain the results by itself. Even though the natural environment of the Baltic Sea is considered as a constraint in winter time and has impacted on people's practices, the following hypothesis can be suggested: the varied adaptability of Finnish and Latvian populations to sea ice environment is largely related to the history and economical and contemporary developments.

\section{Maritime winter shipping}

Besides affecting the lifestyle of Finnish and Latvian societies, the spatial and temporal variability of sea ice has an indubitable impact on maritime activities, especially winter shipping. For centuries, the Baltic Sea has been a significant maritime crossroads for trade. Some major harbours of Southern Baltic were part of the Hanseatic League which had an important trading role in Northern Europe since the Middle Age (Dollinger 1988). Since then, the maritime traffic of the Baltic and the internationalization of its trade have grown with the intervention and diffusion of new techniques of navigation. From 1997 to 2007, the aggregated volume of cargo handled in the Baltic Sea ports grew from approximately 580 million to 825 million tons (Saurama 2010).

Until 1970, the winter navigation was limited to the Southern Baltic. Steamboats were replacing sailing boats and few icebreakers were in operation during the interwar period. In the 1950's, despite significant technical advances in shipbuilding materials, the operation of new icebreakers and the first regulations (Siivonen 1979), winter navigation was almost nonexistent in the Gulf of Bothnia.

Thereafter the contemporary winter navigation has been made possible by technical developments:

- the establishment of ice-class rules depending on the severity of sea ice conditions and the power of boats;

- the winter maritime restrictions which are set up for each port every winter according to the ship ice-class and deadweight tonnage;

- and the increasing number of icebreakers, the construction of the Finnish-Swedish icebreaker fleet and the icebreaker assistance.

The icebreaking operations largely depend on the severity of ice conditions. For instance, during the severe winter 2006, about 1870 ships were assisted by icebreakers in the Bay of Bothnia and 215 in the Gulf of Riga. But in 2008, quite mild winter, only 691 ships needed the assistance of an icebreaker in the Bay of Bothnia and none in the Gulf of Riga. Besides, port facilities have been adapted to ice conditions such the air bubbler system (Pan \& Eranti 2009) and new information and communication technologies as the IBNet (IceBreaking Net) have improved the icebreaking and assistance operations.

The study has shown that growth factors are related to a better administrative, legal and technical control of winter shipping conditions in the whole Baltic basin rather than a simple consequence of a possible change in the meteorological and marine system of sea ice. Nowadays, despite the severe Baltic Sea ice conditions, winter traffic accounts for one quarter of the annual traffic (Lépy 2012). For instance, in 2005, ports of the Bay of Bothnia and the Gulf of Riga were totally frozen and despite this, the accumulated winter traffic from January to March was $25,6 \%$ in Oulu and $25,8 \%$ in Riga $^{2}$. Seasonal variations in winter traffic which were obvious in the seventies are not visible anymore.

\section{Sea ice-related risks}

Practicing an activity on sea ice, whether for work or leisure, inevitably encounters risk, even if incidents and accidents are fewer on sea ice than in free water. Sea ice is a temporary and moving environment which makes people be more vulnerable. The complex and multidisciplinary concept of risk can be defined as the "perception of the pos- 
sible danger, more or less predictable by a social group or a person who is exposed to" (Veyret 2003). In this context, the risk results from the combination of meteorological hazards (temperature decrease, fog formation, strong winds, etc.), sea ice-related hazards (ice pack fractures, ridged ice formation, presence of a water layer between two layers of ice, water level changes, etc.) and geographical factors (short day length and the spatial immensity of sea ice) with the vulnerability of coastal societies of the Baltic Sea (Lépy 2009). Due to the differences in societal adaptations to sea ice conditions, the research question deals with the vulnerability of Finnish and Latvian societies and if sea ice represents a societal risk in the Baltic area (Lépy 2008).

Risks for coastal populations are real in the Bay of Bothnia with more than ten cases per winter involving one person to groups. Archives from Virpiniemi Coast Guard station and statistical data treatment have shown that between 1990 and 2001, 23\% of incidents and accidents involved snowmobiles, $13,5 \%$ some walkers and 10,8\% some cross-country skiers in the maritime area of Oulu Coast Guard (Lépy 2009). Reasons for such incidents or accidents are mainly related to loss (24\%), weather conditions $(21 \%)$ and mechanical and technical problems (11\%). On the other hand, risks are very limited in the Gulf of Riga due to the low frequenting of sea ice.

Risks related to winter navigation (Lépy 2012) mainly concern ships with ice class superior to IA, the ones who are authorized to sail in wintertime. The type of damages is variable and often affects the propeller, rudder, hull or ship's hold. Technical errors such the ship speed, manoeuvring error and the collision between two ships are the main causes (Hänninen 2003).

The risk management is then very developed especially in the Northern Baltic and is based on three elements: 1) prevention has an important role of informing local populations about weather and ice conditions; 2 ) protection is emphasised by the coast guard operations, more severe restrictions for ice classes, a more efficient assistance of icebreakers and the expansion of the FinnishSwedish icebreaker fleet, and 3) search and rescue operations are led by the coast guards. Despite a significant effort to avoid incidents and accidents on sea ice, many people are still exposed to danger. Depending on natural hazards and human vulnerability Baltic Sea ice can represent a danger for societies.

\section{Discussion}

The question about future evolutions related to environmental and socio-economic aspects of the Baltic Sea is the heart of the discussion. The dependence of sea ice formation, growth and melting to climatic factors has been clearly shown in this research (Lépy 2009). Because of its sensitivity to winter air temperature variations, sea ice can constitute a suitable indicator of climate change (Tinz 1996). In the context of global warming, the history of sea ice conditions has been taken into account through the phenomenon analysis at two geographical scales: the Baltic and regional scales. At a Baltic scale, even uncertainties exist in the data from the $18^{\text {th }}$ and $19^{\text {th }}$ centuries due to different methods of ice observations, the maximum ice extent from 1720 (Fig. 3) shows an inter-annual variability of ice phenomenon but not a significant trend for climate change. In fact, according to Haapala and Leppäranta (1997) and Vihma and Haapala (2009), the maximum annual ice extent in the Baltic Sea has not shown any clear trends during the last century. At a regional scale, a stability of sea ice characteristics can be observed at Oulu since 1930's as it is shown in the figure 4. The same kind of documents have been produced for other Baltic coastal stations (Lépy 2009). First, the graphics show that sea ice season length is obviously longer in the North of the Gulf of Bothnia than in the South where fluctuations are more important. Second, sea ice profiles of the Swedish and Finnish coasts are slightly different and show a coastal opposition with a trend of decreasing sea ice season on the West coast and stability on the East coast. However, it seems difficult to express a common trend for the whole Baltic basin. While many works conform to the current scientific trend in their conclusions, it seems opportune to raise the question of the relevance of the Baltic case within global warming context.

The future of Baltic Sea ice conditions is not certain. From the most recent observations, there is not a total agreement on the forecasts. For instance, while previous assessments expected already a clear reduction of sea ice, Baltic Sea ice was still formed every winter in the Bay of Bothnia and the eastern parts of the Gulf of Finland and sea ice should still appear at Kemi in 2100 according to Haapala and Leppäranta (1997). Even if some scientists (Haapala et al. 2001; Meier et al. 2004; Christensen et al. 2007; Jylhä et al. 2008) forecast a significant reduction of Baltic Sea ice extension 


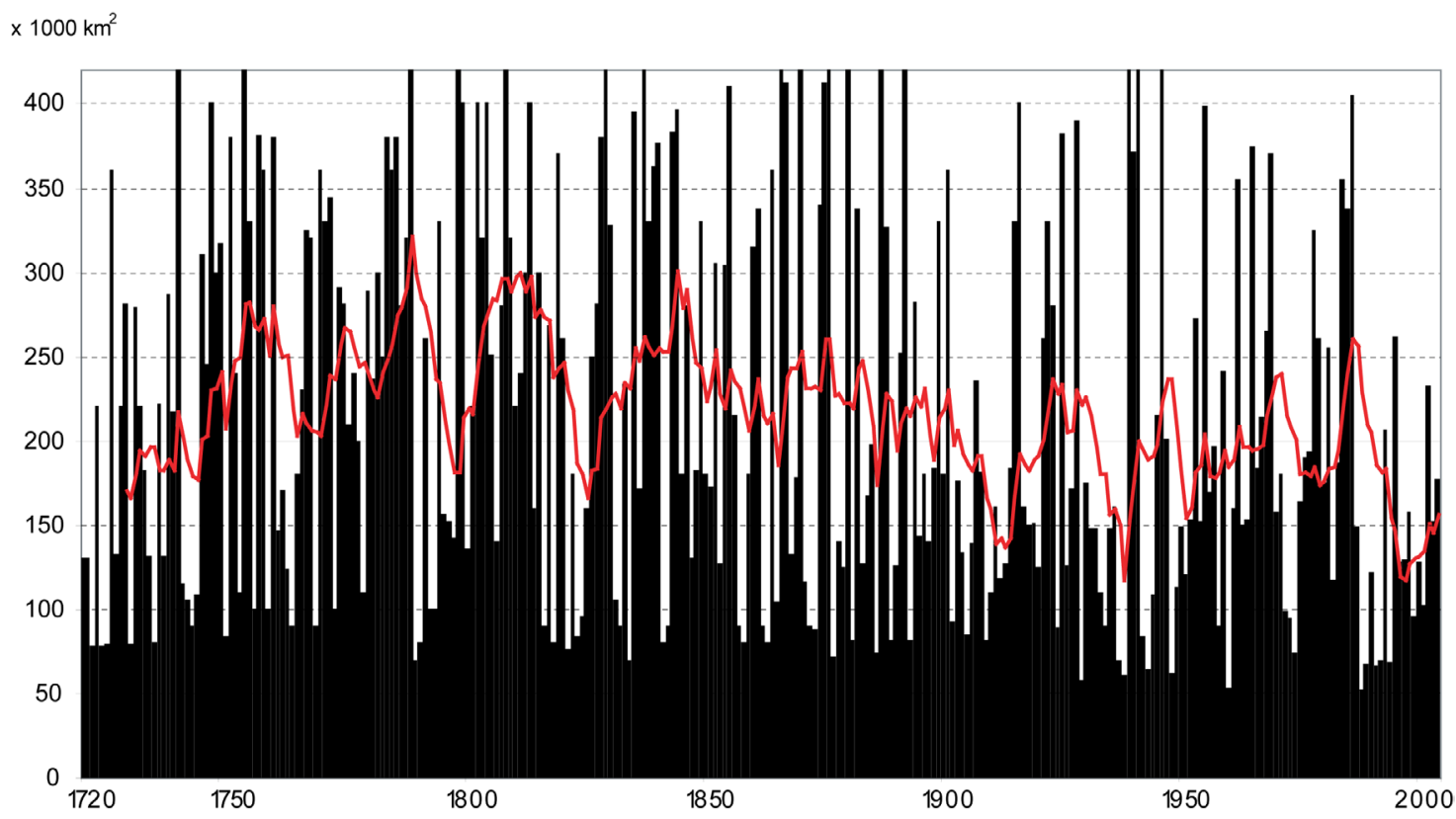

Fig. 3. Maximum ice extent of the Baltic Sea and 10-year moving average for the period 1720-2005. Data source: Seinä \& Palosuo 1996; Seinä et al. 2001; Seinä et al. 2006.

on the order of $35 \%$ to $55 \%$, the future of sea ice conditions is balanced since the regional analysis shows a general variability of sea ice characteristics for a century. Therefore, it seems important to moderate global scale generalizations within a scalar approach of macro-regional and regional scale. Nevertheless, the natural variability of sea ice phenomena has always existed leading to various variations of sea ice features with unavoidable consequences on marine and human environment of the Baltic Sea.

Consequently, numerous questions are prompted on environmental and economic evolution in the future the Baltic Sea. The first issues concern the repercussions of winter sea ice reduction on society lifestyle, professional and recreational activities, and maritime and port activities but also the negative effects on landscape and wildlife. According to the interviews conducted with sea ice "users", it seems that coastal populations are not so worried about the future and its environmental uncertainties and they are ready to adapt themselves to new changes. Regarding the future of the winter navigation, the shortening of ice season would be positive for icebreaking activities which would be reduced as well as delays in winter traffic and port operations (coming alongside etc.). The shipping season in ice free waters would be extended as well as the ship speed increased leading to a growth in traffic. Risk of accidents could then remain as it is nowadays (Lépy 2012). In another system of considerations, it is possible to perceive the early beginnings of a new regional order in a future change of this maritime area due to a possible climate change and geopolitical and economic transformations. The Baltic Sea has always been a geostrategic, geopolitical and geoeconomic area where confrontations and exchanges occurred from the Hanseatic League in the Middle Age to the Fall of the Berlin wall. Nowadays, the Baltic area is considered as a new economic area with many regional cooperations such the Union of Baltic Cities (UBC in 1991) or the Baltic ports Organization (BPO in 1991). Considering that the establishment of the Hanseatic League was possible due to a better climate favourable to the maritime circulation, it is possible to conceive that the Baltic Sea could form a new hanseatic area! 
OULU

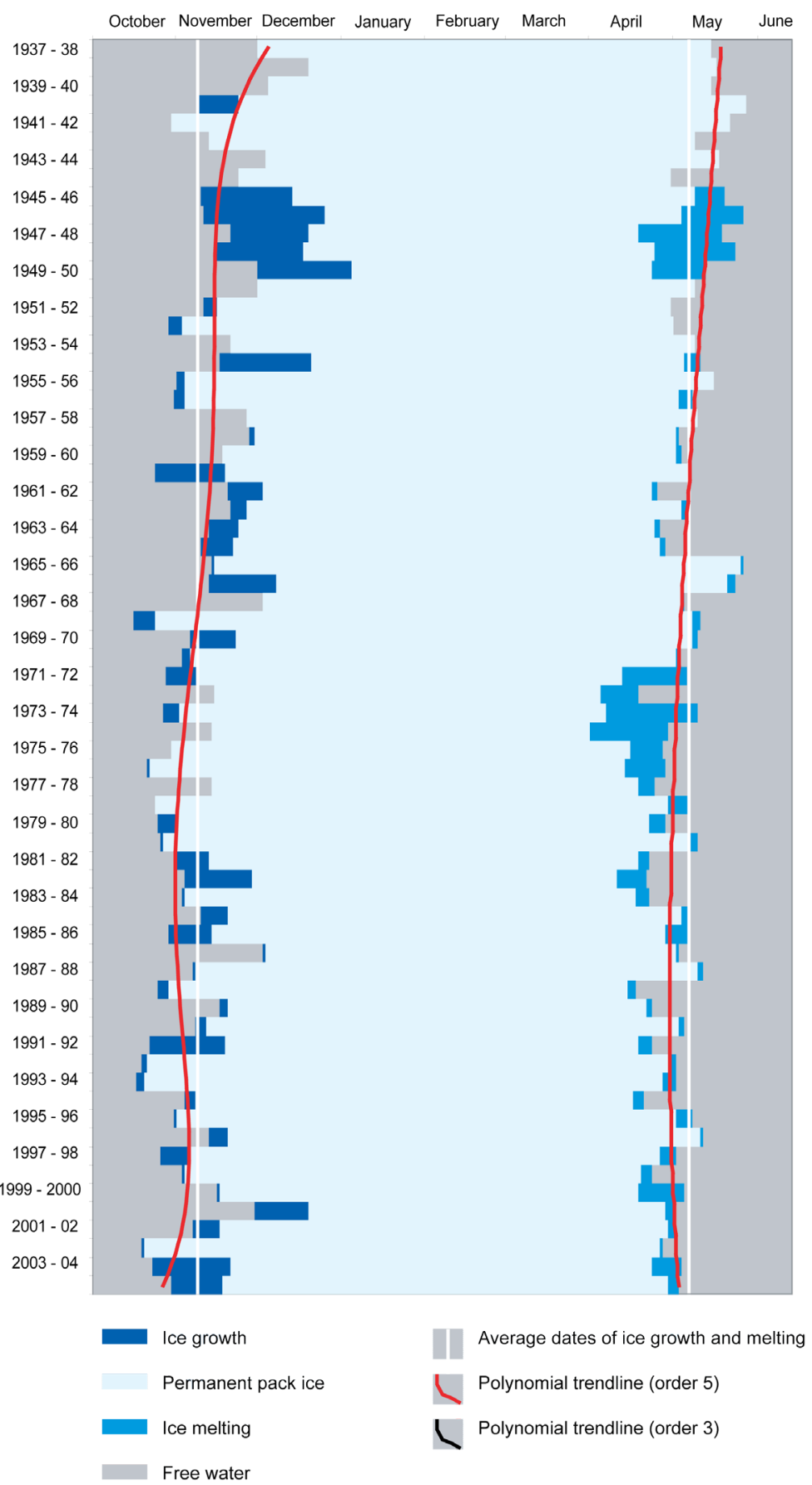

Permanent sea ice length (5-year period)

406080100120140160180200 days

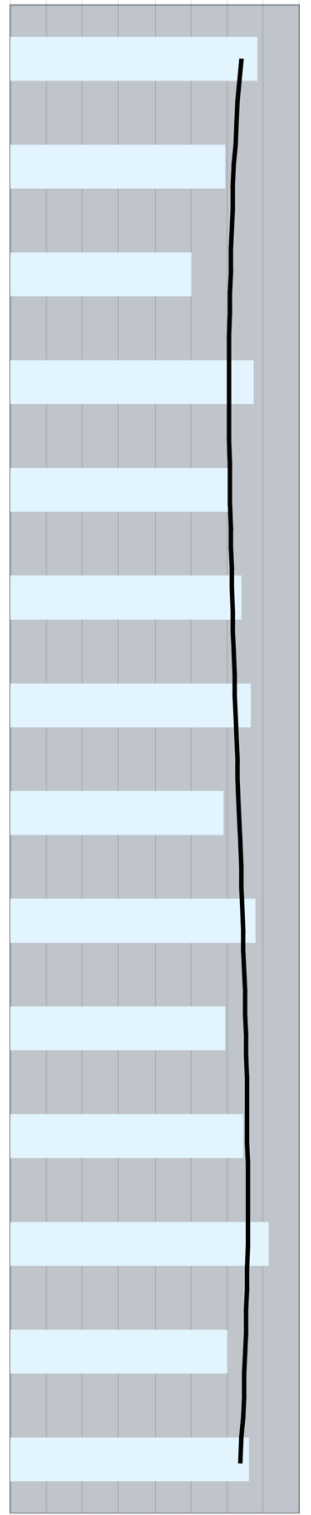

Fig. 4. Sea ice characteristics at Oulu from 1937 to 2005. Data source: Granqvist 1928a, 1928b, 1929, 1930, 1931, 1932, 1933, 1936; Jurva 1935, 1936, 1948; Simojoki 1952, 1956; Palosuo 1957, 1958, 1959, 1960, 1961a, 1961b, 1962, 1964, 1965, 1966, 1971; Jurva \& Palosuo 1959; Kalliosaari 1978, 1982; Kalliosaari \& Seinä 1987; Seinä \& Kalliosaari 1991; Seinä et al. 1996, 2001; Seinä et al. 2006. 


\section{Conclusion}

This study aimed to contribute to a comparative analysis of the relations between environmental and societal dynamics on the coastal areas of the Bay of Bothnia and the Gulf of Riga. The originality of this work lies primarily on a multidisciplinary approach, while most researches in this field have the tendency to focus on rather specific fields. Moreover, it contributes to the understanding of sea ice processes, which have been understudied in coastal and maritime geography, and particularly, with regards to the case of the Baltic Sea.

The research outcomes can be briefly summarized by the following points concerning the natural environment: a) the interannual variability of Baltic Sea ice and the peculiarity of seasonal development of sea ice due to various geographical settings; b) the large internal diversity at regional or local scale of the interannual evolution of sea ice with a more important variability on the Southern part of the Baltic Sea; and c) a certain modesty of geomorphological effects of sea ice action on shores.

Despite the harshness of the climatic and cryomarine environments, the study has shown that they do not prevent different societal and cultural practices, occupation forms and economic developments, which are the result of remarkable adaptability of populations. Indeed, regarding the maritime development, the growth factors are clearly related to a better administrative, legal and technical management of the winter navigation rather than to simple changes in sea ice conditions.

Finally, the future environmental and socio-economic evolutions due to changes in sea ice conditions have to be carefully considered especially when applying global warming scenarios to the macro-regional scale of the Baltic Sea. In that sense, the Baltic Sea ice is not necessarily an indicator of a global evolution.

Although one can argue that this comparative study between the Bay of Bothnia and the Gulf of Riga is slightly unbalanced for more data being available for the former, it has produced relevant geographical knowledge about the Baltic Sea ice and related impacts on environment and societies. It can be considered as a basis for broader research to other Baltic Sea waters such the South of the Gulf of Bothnia or the Gulf of Finland.

\section{NOTES}

1 This article is a reduced version of the academic dissertation "Les glaces de mer en Mer Baltique. Étude géographique et implications environnementales et sociétales à partir de l'étude comparée de la Baie de Botnie (Oulu, Finlande) et du Golfe de Riga (Lettonie)", University of Caen-Lower-Normandy, 419 p., publicly defended in November 2009. It is the first research on Baltic Sea ice conducted within a French academic institution.

${ }^{2}$ Figures calculated based on the data provided by the Port of Oulu and the Marine Administration of Latvia.

\section{ACKNOWLEDGEMENTS}

The author would like to thank Professor Emeritus Armel Coudé, University of Caen-Lower-Normandy, France for providing scientific supervision during the doctoral research as well as scientists and local actors who have contributed to this work. The author also acknowledges the three anonymous reviewers for their constructive comments.

\section{REFERENCES}

Alestalo J \& Häikiö J 1976. Ice features and ice-trust shore forms at Luodonselkä, Gulf of Bothnia, in winter 1972/73. Fennia 144, 1-24.

Alestalo J, Heikinen O \& Tabushi H 1986. Sea ice deformation in the Bothnian Bay off Hailuoto, Finland, in March 1986. Bothnian Bay reports 4, 51-63.

Christensen J, Hewitson B, Busuioc A, Chen A, Gao X, Held I, Jones R, Kolli R, Kwon W-T, Laprise R, Magaña Rueda $V$, Mearns L, Menéndez C, Räisänen J, Rinke A, Sarr A \& Whetton P 2007. Regional climate projections. In Solomon S (ed). Climate change 2007: The physical science basis. Contribution of working group I to the fourth assessment report of the Intergovernmental Panel on Climate Change, 847-940. Cambridge University Press, Cambridge.

Dollinger P 1988. La Hanse XIİ-XVIİ siècles. Aubier, Paris.

Eberhards G 2003. Latvijas jūras krasti. Latvijas Universitāte, Riga.

Eronen M 2005. Land uplift: virgin land from the sea. In Seppälä M (ed). The physical geography of Fennoscandia, 17-34. Oxford University Press, Oxford.

Granqvist G 1928a. Yleiskatsaus talven 1926-27 jääsuhteisiin. Merentutkimuslaitoksen Julkaisu 55, $1-52$. 
Granqvist G 1928b. Yleiskatsaus talven 1927-28 jääsuhteisiin. Merentutkimuslaitoksen Julkaisu 56, $1-56$.

Granqvist G 1929. Yleiskatsaus talven 1928-29 jääsuhteisiin. Merentutkimuslaitoksen Julkaisu 64, $1-48$.

Granqvist G 1930. Yleiskatsaus talven 1929-30 jääsuhteisiin. Merentutkimuslaitoksen Julkaisu 71, $1-33$.

Granqvist G 1931. Yleiskatsaus talven 1930-31 jääsuhteisiin. Merentutkimuslaitoksen Julkaisu 79, $1-54$.

Granqvist G 1932. Yleiskatsaus talven 1931-32 jääsuhteisiin. Merentutkimuslaitoksen Julkaisu 85, $1-52$.

Granqvist G 1933. Yleiskatsaus talven 1932-33 jääsuhteisiin. Merentutkimuslaitoksen Julkaisu 87, $1-42$.

Granqvist G 1936. Yleiskatsaus talven 1935-1936 jääsuhteisiin. Merentutkimuslaitoksen Julkaisu 108, 1-47.

Guilcher A 1958. Coastal and submarine morphology. Methuen, London.

Haapala J 2000. Modelling of the seasonal ice cover of the Baltic Sea. Report series in geophysics 42.

Haapala J \& Leppäranta M 1997. The Baltic Sea ice season in changing climate. Boreal environment research 2, 93-108.

Haapala J, Meier M \& Rinne J 2001. Numerical investigations of future ice conditions in the Baltic Sea. Ambio 30: 4-5, 237-244. http://dx.doi.org/10.15 79\%2F0044-7447-30.4.237.

Hänninen S 2003. Incidents and accidents in winter navigation in the Baltic Sea, winter 2002-2003. Winter navigation research board 54.

Jevrejeva S, Drabkin V, Kostjukov J, Lebedev A, Leppäranta M, Mironov Y, Schmelzer N \& Sztobryn M 2004. Baltic Sea ice seasons in the twentieth century. Climate Research 25, 217-227. http://dx. doi.org/10.3354\%2Fcr025217.

Jurva R 1935. Yleiskatsaus talven 1933-34 jääsuhteisiin. Merentutkimuslaitoksen Julkaisu 97, 1-71.

Jurva R 1936. Yleiskatsaus talven 1934-35 jääsuhteisiin. Merentutkimuslaitoksen Julkaisu 102, 1-65.

Jurva R 1937. Über die Eisverhältnisse des Baltischen Meeres an den Küsten Finnlands. Merentutkimuslaitoksen Julkaisu 114, 1-51.

Jurva R 1948. Yleiskatsaus talven 1936-37 jääsuhteisiin. Merentutkimuslaitoksen Julkaisu 113, 1-71.

Jurva R 1952a. A general handbook on the geography of Finland. Fennia 72, 136-160.

Jurva R 1952b. On the variations and changes of freezing in the Baltic during the last 120 years. Fennia 75, 17-24.

Jurva R \& Palosuo E 1959. Die Eisverhältnisse in den Finnland umgebenden Meeren in den Wintern 1938-45 und die Baltischen Eiswochen in den Wintern 1938-39. Merentutkimuslaitoksen Julkaisu 188.

Jylhä K, Fronzek S, Tuomenvirta H, Carter T \& Ruosteenoja K 2008. Changes in frost, snow and Baltic sea ice by the end of the twenty-first century based on climate model projections for Europe. Climate change 86, 441-462. http://dx.doi. org/10.1007\%2Fs10584-007-9310-z.

Kalliosaari S 1978. Jäätalvet 1971-75 Suomen merialueilla. Finnish Marine Research 245, 1-63.

Kalliosaari S 1982. Jäätalvet 1976-80 Suomen merialueilla. Finnish Marine Research 249, 3-61.

Kalliosaari S \& Seinä A 1987. Jäätalvet 1981-85 Suomen merialueilla. Finnish Marine Research 254, $1-63$.

Kullenberg G 1981. Physical oceanography. In Voipio A (ed). The Baltic Sea, 135-181. Elsevier oceanographic series, Amsterdam.

Leppäranta M 1993. The Baltic Sea ice climate: an introduction. Report series in geophysics 27, 5-16.

Leppäranta M \& Lensu M 1992. ERS-1 Baltic Sea ice calibration/validation, post-experiment report/PIPOR/Finlnad, Internal report 1992 (9). Finnish Institute of Marine Research, Helsinki.

Leppäranta M, Makkonen L, Palosuo E \& Kuusisto E 2001. Geophysics of snow and ice in Finland during the 1900s. Geophysica 32: 1-2, 261-285.

Leppäranta M, Sun Y \& Haapala J 1998. Comparisons of sea-ice velocity fields from ERS-SAR and a dynamic model. Journal of Glaciology 44: 147, 248-262.

Leppäranta M \& Thompson T 1989. BEPERS-88 Sea ice remote sensing with synthetic aperture radar in the Baltic Sea. Eos 70: 28, 698-709. http://dx. doi.org/10.1029\%2F89EO00216.

Lépy E 2007. Influence of the temperature on ice conditions in the Bay of Bothnia. Berichte des Bundesamtes für Seeschifffahrt und Hydrographie 42, 23-28.

Lépy E 2008. Information and communication technologies, a tool for risk prevention and accident management on sea ice. The case of the Bay of Bothnia (Baltic Sea). NetCom 22: 3-4, 255-264.

Lépy, E 2009. Les glaces de mer en Mer Baltique. Étude géographique et implications environnementales et sociétales à partir de l'étude comparée de la Baie de Botnie (Oulu, Finlande) et du Golfe de Riga (Lettonie). University of Caen Lower-Normandy, Doctoral dissertation. <http:// tel.archives-ouvertes.fr/tel-00444566/fr/>

Lépy $E$ 2012. The recent history of winter Finnish navigation in the Baltic Sea. Polar Record, available on CJO2012. doi:10.1017/S0032247411000 593.

Meier M, Döscher R \& Halkka A 2004. Simulated distributions of Baltic sea-ice in warming climate and consequences for winter habitat of the Baltic ringed seal. Ambio 33: 4, 249-256. http://dx.doi. org/10.1579\%2F0044-7447-33.4.249.

Pagney P 1989. Les climats côtiers de la Mer Baltique. Hommes et Terres du Nord 3, 167-170.

Palosuo E 1953. A treatise on severe ice conditions in the Central Baltic. University of Helsinki, Doctoral dissertation. 
Palosuo E 1957. Die Eisverhältnisse in den Finnland umgebenden Meeren im Wintern 1955-56. Merentutkimuslaitoksen Julkaisu 174, 1-14.

Palosuo E 1958. Die Eisverhältnisse in den Finnland umgebenden Meeren im Wintern 1956-57. Merentutkimuslaitoksen Julkaisu 178, 1-24.

Palosuo E 1959. Die Eisverhältnisse in den Finnland umgebenden Meeren im Wintern 1957-58. Merentutkimuslaitoksen Julkaisu 187, 1-22.

Palosuo E 1960. Jäätalvi 1958/59 Suomen merialueilla. Merentutkimuslaitoksen Julkaisu 191, 1-18.

Palosuo E 1961a. Jäätalvi 1959/60 Suomen merialueilla. Merentutkimuslaitoksen Julkaisu 196, $1-22$.

Palosuo E 1961b. Jäätalvi 1960/61 Suomen merialueilla. Merentutkimuslaitoksen Julkaisu 200, 1-28.

Palosuo E 1962. Jäätalvi 1961/62 Suomen merialueilla. Merentutkimuslaitoksen Julkaisu 206, 1-24.

Palosuo E 1964. Jäätalvi 1962/63 Suomen merialueilla. Merentutkimuslaitoksen Julkaisu 213, 1-28.

Palosuo E 1965. Jäätalvi 196/64 Suomen merialueilla. Merentutkimuslaitoksen Julkaisu 217, 1-24.

Palosuo E 1966. Jäätalvi 1964/65 Suomen merialueilla. Merentutkimuslaitoksen Julkaisu 220, 1-20.

Palosuo E 1971. Jäätalvi 1966/70 Suomen merialueilla. Merentutkimuslaitoksen Julkaisu 234, 1-63.

Pan H \& Eranti E 2009. Flow and heat transfer simulations for the design of the Helsinki Vuosaari harbor ice control system. Cold regions science and technology 55: 3, 304-310. http://dx.doi.org/ $10.1016 \% 2$ Fj.coldregions.2008.09.001.

Planchon O 1997. Les climats maritimes dans le monde. Presses Universitaires du Septentrion, Villeneuve d'Asq.

Roussel I 1989. La chaîne des Scandes: une barrière climatique? Hommes et Terres du Nord 3, 161-166.

Saurama A 2010. Baltic maritime transport. Baltic Transport Journal 1, 16-18.

Seinä A, Erönvall H, Kalliosaari S \& Vainio J 1996. Ice seasons 1991-1995 in Finnish sea areas. Meri 27, $3-77$.

Seinä A, Erönvall H, Kalliosaari S \& Vainio J 2001. Ice seasons 1996-2000 in Finnish sea areas. Meri 43, 3-98.
Seinä A, Eriksson P, Kalliosaari S \& Vainio J 2006. Ice seasons 2001-2005 in Finnish sea areas. Meri 57, $3-77$.

Seinä A \& Kalliosaari S 1991. Jäätalvet 1986-90 Suomen merialueilla. Finnish Marine Research 259, 3-61.

Seinä A \& Palosuo E 1996. The classification of the maximum annual ice extent of ice cover in the Baltic Sea 1720-1995. Meri 27, 79-91.

Siivonen O 1979. The development of Finnish ice class rules. In Finnish board of navigation (ed). Ice, ships and winter navigation - Symposium in Oulu university 1977 in connection with the 100 year celebration of Finnish Winter Navigation, 154-171. Finnish Board of Navigation, Helsinki.

Simojoki H 1952. Die Eisverhältnisse in den Finnland umgebenden Meeren in den Wintern 1946-50. Merentutkimuslaitoksen Julkaisu 154.

Simojoki H 1956. Die Eisverhältnisse in den Finnland umgebenden Meeren in den Wintern 1951-55. Merentutkimuslaitoksen Julkaisu 171.

Swedish Meteorological and Hydrological Institute \& Finnish Institute of Marine Research 1982. Climatological ice atlas for the Baltic Sea, Kattegat, Skagerrak and Lake Vänern. SMHI \& FIMR, Norrkoping.

Thompson T \& Leppäranta M 1987. BEPERS-88 Experiment plan. Winter Navigation Research Board 46.

Tikkanen M \& Oksanen J 2002. Late Weichselian and Holocene shore displacement history of the Baltic Sea in Finland. Fennia 180: 1-2, 9-20.

Tinz B 1996. On the relation between annual maximum extent of ice cover in the Baltic Sea and sea level pressure as well as air temperature field. Geophysica 32: 3, 319-341.

Veyret $Y$ 2003. Les risques. Sedes, Paris.

Vihma T \& Haapala J 2009. Geophysics of sea ice in the Baltic Sea: A review. Progress in Oceanography 80, 129-148. http://dx.doi.org/10.1016\%2Fj. pocean.2009.02.002. 